\title{
Iran-Saudi-Turkish Rivalry and Implications of the Iran- US/West Nuclear Agreement on Wahabis in Indonesia
}

\author{
Herdi Sahrasad ${ }^{1}$, Al Chaidar ${ }^{2}$, Muhammad Ridwan $^{3}$, Dedy Tabrani ${ }^{4}$, Mohamad Asrori \\ Mulky ${ }^{5}$ \\ ${ }^{1}$ Universitas Paramadina and Senior Fellow Centre for Strategic Studies University of Indonesia, \\ Indonesia \\ 2PhD candidate, Anthropology UI dan Lecturer, Fisip Universitas Malikussaleh, Lhokseumawe, Aceh, \\ Indonesia \\ ${ }^{3}$ State Islamic University of Sumatera Utara Medan, Indonesia \\ ${ }^{4} \mathrm{PhD}$ Candidate at PTIK, Police Science College, Jakarta, Indonesia \\ ${ }^{5}$ Islamic College Darul Fatah, Jakarta and researcher at Paramadina Institute of Ethcics and \\ Civilization, Indonesia \\ Email: sahrasad@yahoo.com
}

\begin{abstract}
:
A world agreement on Iran's Nuclear was reached in Vienna, Austria, in July 2015. Negotiations between Iran and the six world powers namely the United States, Britain, France, China, Russia plus Germany began in 2006 and reached an agreement with Iran at the Vienna Meeting in July 2015 in an effort to reduce Iran's nuclear activities in exchange for lifting sanctions or embargoes. international economy that has lasted three decades. United States President Barack Obama (2015) said that with the agreement that opened the new page, all Iranian nuclear weapons had been cut off for Iran so that the Middle East nuclear power was held militarily by Israel. In this regard, international sanctions against Iran are lifted, and Iran has a stronger chance to improve its posture in the international arena. The Vienna Agreement has caused ideological anxiety among Wahabis with the implication that Wahabis are unhappy and they do not like the strengthening of Iran politically and culturally in a globalized world. Wahhabi ideological interests will be eroded to some extent by treaties that will seriously divide the Islamic world by Sunni-Shiite competition. However, the rise of Turkey which is competing with Iran and Saudi Arabia in the Middle East political arena, will open the eyes of Wahabis in Indonesia that it is very likely Turkey is their hope for the future.
\end{abstract}

Keywords:

Iran; Saudi; Sunni; Shiite; Turkish; Islamic; nuclear; US

\section{Introduction}

The World Agreement on Iran's Nuclear was reached in Vienna, Austria, in July 2015. This agreement was the result of a long diplomacy which was finally won by Iran after many of its nuclear scientists were killed. This agreement will change the world geopolitical composition. World powers have reached an agreement with Iran to reduce the country's nuclear activities in return for the lifting of sanctions or an international economic embargo that has lasted three decades. United States President Barack Obama said that with the agreement, all Iranian nuclear weapons had been cut off for Iran so that the Middle East nuclear power would still be held militarily by Israel.

For Iranian President Hassan Rouhani, this opened a "new chapter" of Iran's relations with the world, an opportunity that the Persian dynasty had been waiting for. Talks between Iran and the six world powers (the United States, Britain, France, China, Russia plus Germany) began in 2006. The P5 +1 countries want Iran to reduce nuclear activity which is a 


\section{Britain International of Humanities and Social Sciences (BIoHS) Journal \\ ISSN: 2685-3868(Online), 2685-1989(Print) \\ Vol. 2, No. 2, June 2020, Page: 576-585}

crucial issue to ensure that the country cannot make nuclear weapons.

However, the Middle East still seems to be sliding into tensions and regional conflicts that might escalate. Its focal point is the rivalry of Saudi Arabia and Iran, their proxy and US President Donald Trump. Regional stability seems to depend on a fragile kepercayaan 'trust' 'thread. Saudi military spokesman Colonel Turki Al-Maliki said, "without doubt" that the country's arch-enemy is Iran, which is on the other side of the Persian Gulf.

\section{Research Methods}

The method of preparing this study uses descriptive qualitative. Data collection techniques using literature review. Data sources use publications that can be accessed online (online / online) or verified print sources. Data analysis techniques using qualitative analysis and media critical analysis. The process of data analysis is data reduction, data presentation, and drawing conclusions / verification carried out simultaneously with the process of data collection.

\section{Discussion}

The ideological fears (ideological anxiety, restlessness and worry) of Wahabis everywhere - which has recently been strengthened after the emergence of Al Qaeda and ISIS (Islamic State of Iraq and Syria) as representatives of Wahabi power - are a serious cultural concern for the Islamic world that is split. Garber (1997) proves that even highly ideological personal interests will produce acute cultural anxiety. Surely the Wahhabi communal interests in Indonesia are very large over Iran's strengthening politically and culturally, continuing.

Look at the situation where the Iranian forces that are hated by Wahabis in Indonesia always invite cultural anxiety that is suffocating the bosses of these paradise seekers. Iran, which wants international sanctions that paralyze it repealed, always says its nuclear activities are for peaceful purposes. This condition does not necessarily make Sunni religious people sympathize with Iran, which is a country that supports Shia ideology. Also, there was strong opposition from conservatives in both Iran and the United States. The US Congress has 60 days to consider the agreement, although Obama said he would veto efforts to thwart.

The Wahabis in Indonesia experienced uncertainty in seeing the development of Iranian diplomacy in the world and also in Indonesia. At the world level, Iran's nuclear negotiations with the P5 +1 group, namely the five permanent members of the United Nations Security Council (DK) (United States, Britain, France, Russia, and China) plus Germany and the High Commissioner for Foreign Policy of the European Union finally found a point the final after 22 months. At the national level, Sunnis are generally shocked by the progress of opening Western isolation against Iran. An agreement on Iran's nuclear program was reached in Vienna, Austria, (07/14/2015) to overcome Western suspicion of a program that Iran declared peaceful, and thus sanctions were lifted, but maintained an arms embargo and a ban on ballistic missile technology.

Western suspicion and Sunni suspicion have so far found a strong hook, but after this agreement, the storyline will turn slightly. Shiite ideology will be increasingly rampant, especially after the Nahdlatul Ulama organization is also held back by figures allegedly supporting the Iranian axis and rejecting the dominance of Saudi Arabia's Sunni-dominated axis. This agreement was established with a commitment to heed the "red line" that has been 
determined by Iran. Regarding the points that benefit Iran in the agreement, as an alarming development, geopolitically and ideologically.

The implication that greatly worries the Wahabis is the election of Haedar Nashir in the recent Muhammadiyah Congress which is seen as intolerant and does not place compassion and defense of extremism. Extremism which for the past three decades has been pinned on stigmatized Iran as an enemy of the West, will change the ideological map not only in the Middle East. Large countries recognize Iran's peaceful nuclear program and respect the Iranian nuclear rights within the framework of international laws and conventions. Iran has experienced a state of injustice imposed by the West all this time, a kind of terror which then changes its ideological behavior and orientation. Echebarria Echabe \& Fernández Guede's (2006) research shows the influence of terrorism on the behavior and ideological orientation of a person or group of organizations significantly.

Iran's international political behavior may change with this nuclear agreement. Iran's nuclear program which was initially distorted as a threat to world peace and security has been straightened out to be the object of Iran's cooperation with the international community according to global standards. The United Nations Security Council (DK-UN) recognizes Iran as a peaceful nuclear power country, including in the fields of nuclear fuel recycling and uranium enrichment. There has been a fundamental change in the pattern of the UNSC's interaction with Iran after the issuance of the UNSC resolution under article 25 of the UN Charter, while remembering article 41 and especially the articles relating to the revocation of previous sanctions against Iran. All of Iran's nuclear facilities remain operational, and none has been stopped or frozen as previously expected by Iran's counterparts. Iranian uranium enrichment continues, and thus the desire to stop enriching uranium is not fulfilled.

The world of science and technology research will make Iran a new attraction for Muslims, in addition to its feminist exoticism. Iran's nuclear infrastructure facilities are still maintained, and no centrifuges have been removed. Research and development activities for all major and current centrifuges continue. Nuclear installations for heavy water production are still maintained and continue to be developed and added to with the latest equipment, technology, trials and installations in collaboration with other parties who have the latest technology in this field. Iran as one of the producers of nuclear fuel, especially enriched uranium and heavy water, will access the international market. Thus, sanctions and restrictions on exports and imports of nuclear fuel, some of which have been running for 35 years, have no effect.

Iran and all its ideological tools will experience liberalization. All economic, financial, banking, oil and gas, petrochemical, trade, supply and transportation embargoes implemented by the European Union and the United States as sanctions for Iran's nuclear program were eventually lifted altogether. The demand for an end to Iran's missile program, especially ballistics, was relaxed into restrictions on Iran's policy regarding missiles that could carry nuclear warheads. The arms embargo on Iran was lifted and replaced with several restrictive provisions. Iran is permitted to import or export some weapons products. Sanctions regarding dual-functional materials are lifted, and thus Iran's needs in this field will be met through Iran's joint commission and P5 +1 . Iranian students are no longer subject to academic sanctions in the fields of science related to nuclear energy.

Technical liberalization is as massive as economic and military liberalization granted by the West. Iran can replace the ideology of weapons by opening isolation. The civil aircraft embargo that has been running for three decades has been lifted, and thus Iran can also access 
parts for upgrades to meet safety standards. Disbursement of Iranian financial assets abroad of US \$ billion which has been frozen and blocked over the past few years due to sanctions. Central Bank of Iran, shipping companies, national oil companies, oil transportation companies and other companies under its auspices, Iranian airlines, and many banking institutions and institutions (around 800 people and companies) have been declared as exiting sanctions. Many Wahhabi circles in Indonesia do not understand all the 'blessings' that Iran has obtained and it is increasingly difficult to rely on conspiracy theories as the sole explanation for the progress of nuclear diplomacy.

What the West has given to Iran is something beyond the expectations of Arab countries in the Middle East. Iran has a greater opportunity to contribute in the markets and sectors of trade, technology, finance and energy. Restrictions on Iranian economic cooperation in all fields, including investment in the oil and gas and petroleum industry sectors, were lifted. Indonesia is also happy with the results of Iran's nuclear agreement in Vienna. There will be wide open opportunities for cooperation between all parties with Iran at the international level in the peaceful destination nuclear energy sector as well as the construction of power plants, reactors for research and the supply of the latest nuclear technology.

The political implications of the agreement include rules on monitoring the location of nuclear facilities in Iran so that UN inspectors can review military locations, but Iran may oppose granting access. Instead, the United Nations said an arms embargo and missile sanctions would only take effect in the next five and eight years. However, if Iran violates the agreement, sanctions will be imposed within 65 days. This UN resolution will support an agreement that will also decide on a mechanism so that all Security Council sanctions can automatically re-apply if Iran violates the agreement.

The Vienna Agreement stipulates that six superpowers, Iran and the European Union will form a Joint Commission to handle complaints if there is a violation. If the complainant is not satisfied with the Commission's decision, the country can bring its complaint to the UN Security Council. The UN Security Council must then vote for a resolution to continue imposing embargoes and sanctions on Iran.

\subsection{Saudi and Iran Political Voltage}

Sunni and Shia rivalry in the Middle East can be read from the intense competition between Iran and Saudi Arabia who continue to try to develop their respective schools. The Saudis are trying to build a Sunni network in Middle Eastern countries with the Wahhabism style. While Iran mobilizes and develops Shiite networks in the Middle East by instilling the spirit of Iran's Islamic revolution.

This ideological competition leads to violent physical and psychological warfare. Middle Eastern experts often refer to the Iran-Saudi religious and political rivalry as the new Cold War in the Middle East. Shia followers living in Saudi Arabia, such as Nimr al Nimr, try to shake the Saudi Wahabi domination from within. No wonder the government of the kingdom of Saudi Arabia sentenced him to death and executed the Shiite followers at the end of December 2015.

In 2015, after the execution of 47 inmates including the famous Shia cleric, Sheikh Nimr Baqir al-Nimr, Saudi Arabia continued to reap protests and criticism. The Islamic Republic of Iran is one of the countries most strongly denouncing the Saudis, because the majority of its citizens are adherents of the Shiite sect. 
As a result of this execution problem, Iranians staged a mass protest, which led to the burning of the Saudi embassy in the capital city of Tehran. This then triggered the break of diplomatic relations between the two countries. The Shia adherents are not only Iran. Shiites in Bahrain, Yemen and Iraq also marched at condemning the Saudis who adhered to Sunni schools of thought.

Saudi Arabia severed ties with Iran amid a death row clash against Saudi Arabia's leading Shiite cleric, Sheikh Nimr al-Nimr. The two forces are at opposite positions in a number of regional conflicts. Iran warned that Saudi Arabia would face "Divine retaliation" related to the execution, and the Saudi Embassy in Tehran was attacked by angry protesters.

Since the Iranian Islamic Revolution led by Ayatollah Khomeini in 1979, Saudi Arabia and Iran have been building complex diplomacy, based on mutual suspicion, competition, and hostility. The trigger is not just a difference in Islamic schools. Geopolitically, Iran and Saudi also compete to influence neighboring countries and there is also suspicion about Iran's influence on Shiite minority groups in Saudi Arabia, as well as Shiite communities in Bahrain, Iraq, Syria and Lebanon. Iran's nuclear program and the possibility that it will one day have nuclear weapons, also alarmed Saudi Arabia.

Starting from 1979, at that time the rulers of Saudi Arabia were shocked to witness King Shah Mohammed Reza Pahlavi overthrown by Shia cleric led by Ayatolah Khomeini. Because of 'disappointment and worry at the same time' with the Islamic Republic of Iran, the Saudis then supported Iraq in the Iran-Iraq war in 1980-1988. Iranians protested, because the Saudis allowed Iraq to use chemical weapons. Diplomatic relations between the two countries continued to deteriorate and almost reached its peak in 1987. At that time, 275 Iranians died in clashes in the Holy Land, Mecca from a total of 402 worshipers.

The political rivalry of Iran and Saudi Arabia lasted for a long time because each had equal power, dragged on and locked into a conflict that would last into the future. The tension of political Islam between the Saudis and Iranians is generally seen by the world community as tensions between Sunni and Shia Muslims. Some argue that if the Prophet Muhammad before his death in 632 determined his successor, perhaps all the political tensions would not occur. But because Rasullulah's successor did not exist, the young Islamic group was divided about 30 years after Muhammad SAW died. Most joined in a group called the Sunnis.

The second group consisted of supporters of Ali bin Abi Talib, cousin and son-in-law of Mohammad. The group was called "Shi'at Ali", or followers of Ali, who developed into Shiite Islam. The year 632 in Medina was a problem especially with regard to individual politics. The dispute stems from the question of how to precisely determine Muhammad's successor. Islamic expert Lutz Berger from the University of Kiel, Germany added, "Initially it was a political conflict about the successor and interests of the group. The political conflict was then made into a religious problem."

In the dispute over Muhammad's legitimate successor, it was initially approved by a majority vote that there were four caliphs. In 660, the Umayyad dynasty took power. In the caliph election, for the majority of Muslims, what matters is that they are from the Quraysh tribe, as is Muhammad. While Ali's supporters argue, the successor must come from the family of Muhammad. It was based on argumentation, it was God who determined Ali as his successor, and Muhammad had set it in writing before he died. According to Shia belief, the Sunni group then removed the rule from the Koran. Thus, accusations of counterfeiting the Qur'an were raised by Sunni groups. 
So far, during his presidency, Obama has sought to place Middle Eastern security responsibilities on leaders in the region, especially for allies such as Saudi Arabia who have been given billions of dollars in military machinery by the Americans. But at the same time the Obama administration also withdrew US troops from the dangerous Middle Eastern hot spot. As a result, Arab countries in the Gulf lack trust in US policy in the Middle East. Analysts question: If in Middle East between Shiites and Sunnis, between Arabs and Persians were not united, while Shiites and Persians had nuclear weapons, how could the Arabs accept that?

The Saudi-Iranian conflict has made the West generalize that the Sunni-Shiite conflict in the Middle East will continue. But is it true that the source is about Sunni-Shia, not resource conflicts, geopolitics and the struggle for the arms market? The complexity of the problem seems to coincide with one another in the case of the dispute in the Middle East. Arabs are not eternal allies of the US and Iran is not America's eternal enemy. What happens is a competition of lasting interests between the US, Saudi and Iran to move to secure their respective interests.

In fact, actually Saudi Arabia has been angry with the US for a long time. Especially in 2011, the US actively pushed the wave of the "Arab Spring" revolutionary movement to Saudi Arabia. Although former King Abdullah of Saudi Arabia can quickly stabilize the situation. But Saudi Arabia still remembers that the US is behind the movement. Today, the US actively promotes the normalization of relations with Iran and this encourages Tehran to be more flexible in implementing its Middle East policies. Saudi Arabia has a population of around 24 million, $85 \%$ Sunni faction, and $15 \%$ Shia. Iran is 85 million and $91 \%$ is Shi'ite and $7.8 \%$ is Sunni. Outside of Saudi and Iran there is Turkey who has an interest in playing a role in the Middle East. But what is the basis of the conflict in the Middle East? There are indeed many basic conflicts, but Western analysts generally justify that the most important and most deeply connected and rooted ones are the conflicts between Shiites and Sunnis.

This justification was reinforced by Iran's role in internal strife in Iraq after Saddam Hussein, the strengthening of Hezbollah in Lebanon and Hamas in Palestine because of Tehran's support. The justification also refers to the statement of former Egyptian President Hosni Mubarak who delivered on a TV show in 2006, that: "Many Shiite followers of Egypt are more loyal to Iran than to their country (Egypt)."

Admittedly, the battle between Saudi Arabia and Iran is not only a contestation between religious factions, but also a contestation of power. The two countries are trying to use relatively weak countries in the region to expand their influence. But with the chaos in the Yemeni government and the emergence of Houthi militias, Saudi Arabia is on the side of the losers on this key field. In Syria, Lebanon and Iraq, Iranian influence continues to grow, even making Saudi Arabia worse.

The question: Then from whom will Saudi Arabia get even stronger support? Saudi Arabia is the largest and richest country in the Arab world. But technology and industry are not as advanced as Egypt. The military has the best equipment, but as far as its combat capability is very low, its military has never been tested on a large scale.

In fact, before General Al-Sisi became President of Egypt, former King Abdullah of Saudi Arabia had expressed strong support for him. In 2013, after becoming the Egyptian Defense Minister, Al-Sisi, who led the military, then moved to overthrow President Mohamed Morsi. In 2013, when Al-Sisi led the military in a coup overthrowing the Morsi government, Saudi Arabia behind the scenes gave him great support. 
Academics and analysts view Al-Sisi as being able to maintain his leadership and Egypt being able to remain stable, thanks in large part to the main role played by Saudi Arabia behind the scenes. The King of Saudi Arabia became the first foreign head of state to congratulate Al-Sisi and the Egyptian military. Saudi Arabia mobilized the Gulf States of the UAE and Kuwait to provide Egypt with economic assistance exceeding US \$ 12 billion to overcome the economic crisis at that time.

As is known, at that time the Egyptian economy was in trouble and the country should have been in a state of bankruptcy. Egypt's national reserves have declined to less than US \$ 15 billion when Sisi served. In retrospect, Egypt's population of 90 million with reserves of less than US \$ 15 billion can be imagined as to what the conditions of Egypt at that time. Egypt is clearly in a state of bankruptcy.

After Egypt was in the orbit of Saudi politics, the Riyadh government intervened military in Yemen where the Shiites succeeded in seizing power from the hands of the Sunnis. The community of Saudi Arabia not only supports Saudi Arabia's new war in Yemen, but also its new role in the Middle East as the "Police", to fill the void caused by the reluctance of the United States to intervene in the region again. Yemen became a touchstone for Saudi Arabia to test its leadership and military capabilities in the Middle East. The Saudis hope that Egypt, Jordan and other Gulf countries help strengthen Saudi Arabia as police in the Middle East.

Egypt was asked by the Saudis to join selflessly, but Saudi Arabia was very disappointed with Egypt for all its military operations. Because Egypt only sent a few patrol ships Bab-el-Mandeb as symbolic, and Saudi Arabia believes that Egypt's actions are not to attack Yemen to help Saudi Arabia, because it is only more an action to protect the Suez Canal in favor of Egypt. Saudi Arabia is really disappointed in Egypt.

\subsection{Iran and Turkey}

This Iranian nuclear power is seen by Wahabis as an American and Western way to erase the positive image of Turkey which is believed to revive the glory of the past khilafah. For Wahhabs in Indonesia, the image of Saudi Arabia is less than that of Turkey, although they are defending the Saudis in the case of the Shia Hauthi uprising in Yemen. As seen through the media Arrahmah.com which cites the article of the writer Jordan, Ihsan Al Faqih, last December 26 in the media Achahed. Turkey's National Domestic Product in 2013 reached US \$ 100 billion, matching the combined income of 3 countries with the strongest economy in the Middle East; Saudi Arabia, United Arab Emirates, Iran, and supplemented by Jordan, Syria and Lebanon.

Turkey's position with Erdogan's character has succeeded in bringing his country into a big economic leap, ranking 111th of the world to rank 16th, with an average increase of $10 \%$ per year, which means Turkey's entry into the 20 most powerful countries (G-20) in the world. 2023 is the year of the development of the Modern Turkish State that has been declared by Erdogan, which is targeted to become Turkey's number 1 political and economic power in the world! Istanbul International Airport is the largest airport in Europe which holds 1260 aircraft every day, plus Shabiha Airport which holds 630 aircraft every day. Turkish Airline, which is often cursed by mujahidin when going to Afghanistan or to Syria, was ranked the best airline in the world in 3 years in a row. The failure of the military coup in Turkey proved the strength of people's trust in Erdogan and the strength of authority, and the influence of Erdogan on Turkish society who had chosen the path of democracy. 
In 10 years, Turkey has planted 770 million Harjia trees and bears fruit. For the first time in modern Turkey, self-producing steel tanks, aircraft and unmanned combat aircraft, as well as the first multi-functional modern military satellite.

In the world of science, Erdogan in his 10 years of government has established 125 new universities, 189 new schools, 510 new hospitals and 169,000 modern new classes, so that the student-class ratio is no more than 21 people. When the economic crisis struck Europe and America, European and American universities raised tuition fees. While Erdogan freed all tuition fees and schools for his people and became the responsibility of the state. In the past 10 years, Turkey's per capita income, which used to be only 3500 dollars per year, increased in 2013 to 11,000 dollars per year, higher than the per capita population of France. And Erdogan increased the exchange rate of the Turkish currency 30 times! This is nothing compared to Iran. In Turkey, the country is working earnestly to fund 300,000 scientists conducting scientific research towards 2023.

Geopolitically, Turkey's position is also a big hope for Wahhabs in Indonesia. Among Turkey's biggest political successes was Erdogan's success in reconciling the two conflicting parts of Cyprus. He also held peace talks with the Kurdistan Workers' party to stop the bloodshed, and apologized to Armenia, so as to resolve the problem that had been hanging for six decades. In Turkey, salaries and wages have risen by $300 \%$. And salaries for new employees increased, from 340 Turkish lira to 957 lira. And the number of job seekers decreased from $38 \%$ to $2 \%$. In Turkey, the education and health budget, outperformed the defense budget, and teacher salaries amounted to doctor salaries. This made the visit of the President of Turkey, Erdogan, greeted hysterically by the Wahabis in Indonesia and they scoffed at Jokowi who refused to accept him for Friday prayers together at the Istiqlal Mosque in Jakarta in early August 2015.

Compared to Iran which has many nuclear scientists, 35,000 IT laboratories and a modern database have been built in Turkey to train Turkish youths. Erdogan covered a budget deficit of 47 billion dollars. Previously the last installment of the IMF's Turkike debt was 300 million dollars in July. Even Turkey lent the IMF a bad name of 5 billion dollars. Besides that, Erdogan also increased the country's foreign exchange reserves by 100 billion dollars. Ten years ago, Turkish exports were only 23 billion dollars. Now it has risen to 153 billion dollars, reaching 190 countries. The most numerous are cars, the second is electronic equipment. Every 3 electronic devices in Europe, one of which is a Turkish product.

In terms of a sustainable environment, the Erdogan Government started processing waste into power plants, which are used by a third of Turkey's population. And electricity has been enjoyed by $98 \%$ of Turkey's population. Erdogan once sat opposite a 12 -year-old girl, appeared on live television, debated and discussed about the future development of Turkey. He respected the intelligence and enthusiasm of the child. At the same time he educated Turkish children in exemplary debate and discussion and future reading. Erdogan is a friend of Israel, according to Arab secularists. Erdogan gave a hard slap to Israel, and he forced Israel to apologize for the case of the Marmara ship which was shot by Israel. And Turkey gave conditions for lifting the Gaza embargo to accept the apology. Erdogan gave sharp criticism of those who applauded Simon Perez's speech at the World Economic meeting, and he said before leaving the room and returning to Turkey: "It's a shame you applaud this speech, even though Israel has killed thousands of children and women in Gaza."

In an increasingly democratic world, Wahhabs look at Erdogan with hope. Erdogan sprayed his opponents with water. Do not shoot them with fighter planes, or missiles or 
Molotov cocktails. Erdogan refused his daughter to open the hijab at school. So he sent his children to study in Europe to keep their hijab in check, before the hijab was permitted on Turkish campuses. Turkey's resurgence is so fierce it makes hope of the rise of the caliphate into something that is undoubtedly for the Wahabi Jihadi in Indonesia. Wahabi jihadis are a different kind of people from Wahabi Shururi or Wahabi Takfiri. For the Wahhabi Jihadists, the Abubakar Ibrahim Al-Baghdadi (ISIS) caliphate is not the real khilafah. That is a false khilafah, and Turkey will rise (back) to be the true khilafah.

\section{Conclusion}

In world diplomacy, Erdogan the only head of state with his wife visited Burma and met with Muslims there from the region of Myanmar that could be disastrous. This courage of Turkey has satisfied the torment experienced by Mulsim Rohingya. Erdogan revived the teaching of the Koran and Hadith in public schools, after being lost for almost 90 years, eliminated by the secular government. Erdogan established freedom of hijab on Turkish campuses and in parliament. Erdogan is the Muslim leader who made lights on the world's largest suspension bridge on the black sea coast with enormous lighting that reads "Bismillahirrahmanirrahim" In fact, one of the Arab countries made the largest Christmas tree in the world by swallowing up to 40 million dollars. The respect of the Wahhabi jihadis in Indonesia for the Arabs has been wiped out.

For Wahhab jihadis in Indonesia, Turkey is a new hope in the horizon of the modern revival of Islam. Erdogan returned the learning of the Ottoman language in Arabic in state schools. Erdogan released a parade of 10 thousand Muslim children aged 7 years on the streets of Istanbul, with great pride the children would begin the obligation to pray in congregation and memorize the Koran. Perhaps this is the kind of situation that is missed by Wahabi Jihadi in Indonesia.

\section{References}

Bailyn, B. (1992). The ideological origins of the American Revolution. Harvard University Press.

Banafsheh Keynoush, Saudi Arabia and Iran: Friends or Foes?, Palgrave Macmillan; 1st ed. 2016 edition (February 5, 2016)

Czarniawska-Joerges, B. (1988). Ideological control in nonideological organizations. Praeger Publishers.

Echebarria Echabe, A., \& Fernández Guede, E. (2006). Effects of terrorism on attitudes and ideological orientation. European Journal of Social Psychology, 36(2).

Garber, M. B. (1997). Vested interests: Cross-dressing and cultural anxiety. Psychology Press.

Gartner, J., Harmatz, M., Hohmann, A., Larson, D., \& Gartner, A. F. (1990). The effect of patient and clinician ideology on clinical judgment: A study of ideological countertransference. Psychotherapy: Theory, Research, Practice, Training, 27(1), 98.

Herdi Sahrasad, Arab Spring: Risalah Studi Timur Tengah (Indonesian Edition), Paperback, Jakarta: LSAF and Media Institute, September 11, 2013

Herdi Sahrasad and Al Chaidar, Islamism and Fundamentalism (Volume 1) Paperback, University of Malikussaleh Press, May 30, 2012

Jibriel AR, Abu Muhammad. (2015). Fakta Syiah Bukan Islam. Jakarta: Arrahmah Publishing.

Jost, J. T., Napier, J. L., Thorisdottir, H., Gosling, S. D., Palfai, T. P., \& Ostafin, B. (2007). Are needs to manage uncertainty and threat associated with political conservatism or ideological extremity?. Personality and social psychology bulletin, 33(7), 989-1007. 
Laor, N., Wolmer, L., Alon, M., Siev, J., Samuel, E., \& Toren, P. (2006). Risk and protective factors mediating psychological symptoms and ideological commitment of adolescents facing continuous terrorism. The Journal of nervous and mental disease, 194(4), 279286.

Nash, K., McGregor, I., \& Prentice, M. (2011). Threat and defense as goal regulation: from implicit goal conflict to anxious uncertainty, reactive approach motivation, and ideological extremism. Journal of personality and social psychology, 101(6), 1291.

Parry-Giles, Trevor. (1994). "Ideological anxiety and the censored text: Real lives-at the edge of the union 1." Critical Studies in Media Communication 11.1 (1994): 54-72.

Peller, G. (1997). Cultural imperialism, white anxiety, and the ideological realignment of Brown. Race, Law, and Culture: Reflections on Brown Vs. Board of Education, 190220.

Peterson, J. B., \& Flanders, J. L. (2002). Complexity management theory: Motivation for ideological rigidity and social conflict. Cortex, 38(3), 429-458.

Punamäki, Raija Leena. "Can ideological commitment protect children's psychosocial well being in situations of political violence?." Child development 67.1 (1996): 55-69.

Treise, D., Weigold, M. F., Conna, J., \& Garrison, H. (1994). Ethics in advertising: Ideological correlates of consumer perceptions. Journal of Advertising, 23(3), 59-69.

Weber, C., \& Federico, C. M. (2007). Interpersonal attachment and patterns of ideological belief. Political Psychology, 28(4), 389-416.

Wilensky, H. L. (1974). The welfare state and equality: Structural and ideological roots of public expenditures (Vol. 140). Univ of California Press.

https://www.aljazeera.com/news/2019/10/saudi-arabia-iran-steps-indirect-talks-nyt191005171357718.html

https://www.spiegel.de/international/world/usa-saudia-arabia-iran-a-new-conflict-in-themiddle-east-a-1287811.html 